\title{
Analisis Transaksi Logam Mulia Secara Daring Dan Tidak Tunai Menurut Perspektif Fikih Muamalah (Studi Pada Aplikasi Lakuemas dan Tamasia)
}

\author{
Indra Marzuki ${ }^{*}$, A. Nabila Mutiara ${ }^{2}$
}

\section{Abstrak}

Penelitian ini bertujuan untuk mengetahui penerapan transaksi logam mulia secara daring dan tidak tunai menurut perspektif fikih muamalah. Hasil Penelitian ini menunjukkan bahwa yang pertama, alasan diperbolehkannya jual beli emas secara tidak tunai menurut pendapat Ibnu Qayyim dan Ibnu Taimiyyah menyatakan bahwa emas dan perak adalah barang (sil'ah) yang dijual dan dibeli seperti halnya barang biasa, dan bukan lagi tsaman sehingga menjadikan hasil dari istinbat hukum dalam fatwa DSN-MUI No.77/DSNMUI/V/2010 bahwa jual beli emas secara tidak tunai dihukumi mubah. Pada fatwa ini sudah jelas bahwa jual beli emas itu boleh hukumnya. Yang kedua, dalam transaksi logam mulia secara daring dan tidak tunai menurut Menurut Zaid bin Ali adalah penjualan suatu barang secara tunda dengan harga yang lebih tinggi dari harga tunai merupakan salah satu bentuk transaksi yang sah dan dapat dibenarkan selama transaksi tersebut dilandasi oleh prinsip saling ridha antara kedua belah pihak.

Kata Kunci: Transaksi emas; Lakuemas; Tamasia

\section{Abstract}

This study aims to determine the application of online and non-cash precious metal transactions from the perspective of muamalah figh. The results of this study indicate that first, the reason for the permissibility of buying and selling gold in cash in the opinion of Ibn Qayyim and Ibn Taimiyyah states that gold and silver are goods (sil'ah) that are sold and bought like ordinary goods, and are no longer tsaman so that it makes the result of the legal dispute in the DSN-MUI fatwa No. 77/DSN-MUI/V/2010 that buying and selling gold in cash is considered permissible. In this fatwa, it is clear that buying and selling gold is legal. Second, in online and non-cash precious metal transactions according to Zaid bin Ali, the sale of an item is delayed at a price higher than the cash price, which is a form of legal and justifiable transaction as long as the transaction is based on the principle of mutual pleasure between both sides.

Keywords: Gold Transaction; Lakuemas; Tamasia

\footnotetext{
${ }^{1}$ Institut Ilmu Al-Qur'an, Jakarta

${ }^{2}$ Institut Ilmu Al-Qur'an, Jakarta
}

84 Analisis Transaksi Logam Mulia Secara Daring Dan Tidak Tunai Menurut Perspektif Fikih Muamalah

Indra Marzuki \& A. Nabila Mutiara 


\section{PENDAHULUAN}

Jual beli merupakan salah satu bentuk kegiatan ekonomi yang hakikatnya adalah saling tolong menolong sesama manusia dengan ketentuan hukumnya telah diatur dalam syariat Islam. Allah SWT telah menjelaskan dalam kalam-Nya Al-Qur'an dan Nabi SAW dalam hadishadisnya telah memberikan batasan-batasan yang jelas mengenai ruang lingkup tersebut, khususnya yang berkaitan dengan hal-hal yang diperbolehkan dan yang dilarang.

Dalam salah satu fatwa DSN-MUI No.77/DSN-MUI/2010 mengenai jual beli emas secara tidak tunai ini kebanyakan masyarakat saat ini menggunakan pembayaran tidak tunai, baik melalui secara tangguh ataupun angsuran. Sehingga dalam fatwa ini menimbulkan perdebatan perbedaan pendapat mengenai hal tersebut. Maka dari itu dari kalangan ulama memiliki pendapat masing-masing untuk mencari solusi dari masalah yang seringkali terjadi dimasyarakat hingga saat ini. Sehingga pada tanggal 3 Juni 2010 fatwa ini dikeluarkan sebagaimana yang telah dipertimbangkan mengenai transaksi jual beli emas secara tidak tunai.

Dalam fatwanya DSN-MUI tersebut juga mendasarkan fatwanya kepada pendapat para ulama yang membolehkan transaksi jual beli emas secara tidak tunai seperti, Ibnu Taimiyyah, Ibnu Qayyim dan ulama kontemporer yang sependapat. Mereka mengemukakan bahwa pertama emas dan perak adalah barang (si'lah) yang dijual dan dibeli seperti halnya barang biasa dan bukan lagi tsaman (harga, alat pembayaran, uang). Sedangkan pendapat ulama yang tidak membolehkan jual beli emas secara tidak tunai mayoritas pendapat fuqaha, dari mazhab Hanafi, Maliki, Syafi'i dan Hambali yang menyatakan bahwa uang kertas dan emas merupakan tsaman (harga, alat pembayaran, uang) sedangkan, tsaman tidak boleh diperjual belikan secara angsuran maupun tangguh karena hal itu menyebabkan terjadinya riba, kecuali dengan cara tunai (Amin, 2021:92).

Kedua, pada zaman ini manusia sangat membutuhkan untuk melakukan jual beli emas. Apabila tidak dibolehkan jual beli emas secara angsuran, maka rusaklah kemaslahatan manusia dan mereka akan mengalami kesulitan. Sekirannya pintu (jual beli emas secara 
angsuran) ini ditutup, maka tertutuplah pintu utang piutang, masyarakat akan mengalami kesulitan yang tidak terkira.

Sebagaimana dalam pendapat para ulama Syaikh Ali Jumu'ah, mufti al-diyar al-Misriyah, al-Kalim al-Thayyib Fatawa Ashriyah, alQahirah : Dar al-salam menyatakan dalam hadis "Boleh jual beli emas dan perak yang telah dibuat atau disiapkan untuk dibuat dengan angsuran pada saat ini, dimana keduanya tidak lagi diperlakukan sebagai media pertukaran dimasyarakat dan keduanya telah menjadi barang (sil'ah) sebagaimana barang lainnya yang diperjualbelikan dengan pembayaran tunai dan tangguh. Begitu juga yang telah dikemukakan dalam hadis al-Khudri bahwa Rasulullah saw bersabda : "Janganlah kalian menjual emas dengan emas kecuali dengan ukuran yang sama, dan janganlah menjual emas yang ghaib (tidak diserahkan saat itu) dengan emas yang tunai." (al-Thayyib, 2006:136).

Dengan demikian, dalam penetapan fatwa tentang jual beli emas secara tidak tunai DSN-MUI nengacu pada prosedur penentapan metode istidlal kemudian di istinbath-kan untuk membolehkannya transaksi jual beli emas secara daring dan tidak tunai, perdebatan hukum yang digunakan DSN-MUI menggunakan metode istinbath istilahi yaitu yang berdasarkan kemaslahatan masyarakat dalam penetapan suatu ketentuan yang bersumber dalil-dalil yang digunakan serta melalui kaidah-kaidah dalam mengeluarkan fatwa.

Dengan perkembangan zaman yang serba digital banyak mempermudah masyarakat dalam bertransaksi untuk memenuhi kebutuhan sehari-hari dan tidak perlu untuk keluar rumah karena cukup mempunyai internet dan media aplikasi belanja online untuk dapat memilih sesuai yang di inginkan. Sehingga jual beli online menjadi trend serta alternatif yang banyak di gunakan oleh masyarakat. Hampir seluruh kebutuhan manusia baik yang primer maupun sekunder dapat dipenuhi dengan sistem online. Kini pelayanan jual beli emas secara online juga banyak disediakan oleh perusahaanperusahaan emas seperti Tokopedia emas, Jual beli emas pada Bukaemas, Tamasia, Emas Digi, Lakuemas dan Toko Emas lainnya yang berbasis online.

Dalam penelitian ini akan membahas tentang produk investasi emas berbasis online pada media aplikasi lakuemas dan tamasia yang dimana aplikasi lakuemas dan tamasia merupakan platform jual beli

86 Analisis Transaksi Logam Mulia Secara Daring Dan Tidak Tunai Menurut Perspektif Fikih Muamalah

Indra Marzuki \& A. Nabila Mutiara 
emas online pertama di Indonesia yang dapat diaskes melalui website, dan aplikasi mobile serta didukung toko-toko offline diberbagai mall besar Indonesia. (Lakuemas, Mei 2021).

Kedua aplikasi Lakuemas ini sudah terdaftar dalam Asosiasi Fintech Indonesia dan keberadaanya sudah sesuai dengan peraturan Otoritas Jasa Keuangan Nomor : 13/POJK.02/2018 tentang inovasi Keuangan Digital dan merupakan satu-satunya produsen perhiasan emas dan berlian di Indonesia yang sudah memiliki Serifikat SNI Kadar Pas 13-3487-2005. Sedangkan pada Tamasia sudah memiliki dokument legalitas usaha yang telah memenuhi syarat (sah) sebagai badan usaha yang berbasis hukum (Tamasia, Juli 2021). Melihat dari latar belakang masalah di atas, penulis tertarik untuk membahas secara mendalam untuk menyampaikan pemahaman kepada masyarakat untuk menganalisis berupa pencarian fakta, hasil dan ide pemikiran seseorang melalui interaksi serta melakukan generalisasi terhadap penelitian yang dilakukan, agar dapat mudah dipahami secara singkat padat dan jelas maka dari itu Penulis akan menindaklanjutinya secara ilmiah dengan judul "Analisis Transaksi Logam Mulia Secara Daring Dan Tidak Tunai Menurut Perspektif Fikih Muamalah (Studi Pada Aplikasi Lakuemas dan Tamasia).

\section{LANDASAN TEORITIS}

\section{Pengertian Jual Beli Emas}

Jual beli emas dalam Islam sudah Jual beli emas dalam Islam sudah ada ketentuannya sejak 14 abad silam. Dan ketentuan ini relevan hingga akhir zaman walaupun kondisi zamannya berubah. Sebagaimana dalam Hadis dinyatakan :

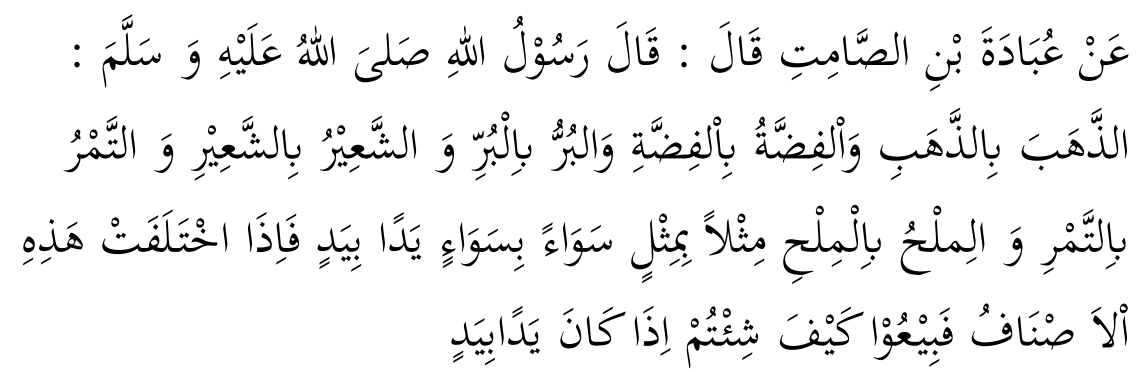

Analisis Transaksi Logam Mulia Secara Daring Dan Tidak Tunai Menurut Perspektif Fikih Muamalah 


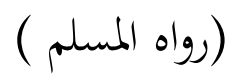

Diriwayatkan dari Ubadah bin as-Shomit Radhiallahu'anhu. Beliau mengatakan bahwa Rasulullah Saw bersabda : "Emas dijual dengan emas, perak dijual dengan perak, gandum dijual dengan gandum, syair (salah satu jenis gandum) dijual dengan sya'ir, kurma dijual dengan kurma, dan garam dijual dengan garam, maka jumlah (takaran atau timbangan) harus sama dibayar kontan (tunai). Bila jenisnya berbeda maka silahkan engkau membarternya dengan cara sesuka hatimu, namun harus dilakukan secara kontan." (HR. Muslim, Jilid 3, Hadis ke 1211)

Pada Hadis diatas.Rasulullah Saw menyebutkan 6 jenis komuditi yaitu: Emas, Perak, Gandum, Sya'ir, Kurma, dan Garam. Enam jenis komoditi pada Hadis diatas lazim disebut dengan komoditi ribawi dalam bahasa ilmu fiqih. Ada ketentuan khusus dalam Islam untuk jual beli atau batner 6 komoditi diatas. Jika jual beli atau batner 6 komoditi tersebut tidak sesuai dengan ketentuan yang sudah ditetapkan Islam maka bisa jatuh pada transaksi riba yang diharamkan oleh Islam.

Enam komoditi ini dikelompokkan oleh para ulama menjadi 2 kelompok, yaitu Kelompok emas-perak dan Kelompok selain emasperak. Kemudian para ulama berbeda pendapat mengenai apa sajakah harta benda yang termask komoditi ribawi dalam dua pendapat :

1. Pendapat pertama, komoditi ribawi hanya sebatas 6 komoditi yang terdapat dalam hadis tersebut. Selain 6 hal ini maka tidak termasuk. Ini adalah pendapat zhahiriyah, karena mazhab zhahiriyah menafikan qiyas secara mutlak (Wahbah Az-zuhaili, t.t:56). Juga merupakan pendapat Ibnu Aqil dari Hanabilah.

2. Pendapat kedua, komoditi ribawi tidak hanya 6 komoditi yang disebutkan oleh hadis, namun juga berlaku pada semua komoditi yang memili illat' yang sama. Sehingga komoditi lain yang memiliki illat' yang sama, di qiyas kan dengan 6 komoditi tersebut (Khallaf, 1972:50).

Inilah pendapat para jumhur ulama. Namun para ulama yang berpendapat adanya qiyas dalam hal ini, mereka berbeda pendapat mengenai illat'nya yaitu

1. Pendapat pertama menurut Hanafiyah dan Hanabilah, illah dari kelompok emas-perak adalah al- waznu, yaitu ditimbang beratnya. 
Sedangkan illah kelompok selain emas-perak adalah al-kaylu, yaitu ditakar ukurannya (Khallaf, 1972:50).

2. Pendapat kedua menurut Asyafi'iyyah, illah dari kelompok emasperak adalah al-tsamaniyah, yaitu digunakan sebagai alat tukar jualbeli. Sedangkan illah kelompok selain emas dan perak adalah althu'mu, yaitu makanan.

3. Pendapat ketigga menurut Malikiyah, illah dari kelompok emasperak adalah al-tsamaniyah. Sedangkan illah kelompok selain emasperak adalah al-quuth al-mudkhar, yaitu makanan pokok yang disimpan.

4. Pendapat ke empat menurut Syaikhul Islam Ibnu Taimiyah, illah dari kelompok emas-perak adalah al-tsamaniyah. Sedangkan illah kelompok selain emas-perak adalah al-thu'mu ma'al- kayli (makanan yang ditakar ukurannya ) atau al-thu'mu ma'al-qazni (makanan yang ditimbang beratnya) (Khallaf, 1972:50).

Pendapat ke empat adalah dinilai lebih rajih oleh Syaikh Khalih AlMusyaiqih, karena pendapat ini menjamak pendapat-pendapat yang ada. Melalui pemahaman ini, dapat diambil kesimpulan bahwa uang adalah komoditi ribawi. Karena uang termasuk al-tsamaniyah, sehingga uang di qiyaskan dengan emas dan perak. Karena ats tsaman adalah segala hal yang engkau berhak mendapat sesuatu dengannya. Kata tsaman juga maknanya tsaman dari jual-beli. Serta tsaman dari sesuatu adalah nilainya (Khallaf, 1972:50).

Jadi dapat diketahui bahwa jual beli emas melalui media online atau aplikasi harus diperhatikan terlebih dahulu bagaimana proses jual beli yang gambarkan melalui media tersebut apakah sesuai dengan akad-akad menurut syariat Islam dan tidak ada unsur Gharar atau penipuan didalamnya.

\section{Dasar Hukum Transaksi Jual Beli Emas}

a. Al-Qur'an QS. Al-Baqarah : 275

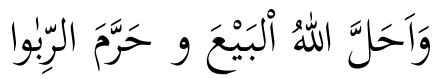

Yang artinya :

"Dan Allah menghalalkan jual beli dan mengharamkan Riba" (QS.AlBaqarah [2] : 275) 
b. Dalam hadis Nabi riwayat Ibnu Majah dan Al-Baihaqi dari Abu Sa'id Al-Khudri:

اَنَّ رَسُوْلَ اللهِ صَلَّى اللهُعَعَلْيْهِ وَ سَلَّمَ قَالَ : إنَّمَا الََبْعُ عَنْ تَرَاضِ (رواه ابن

Rasulullah SAW bersabda: "Sesungguhnya jual beli itu hanya boleh dilakukan atas dasar kerelaan (antara kedua belah pihak)" (HR.Ibnu Majah dan al-Baihaqi,dan dinilai shahih oleh Ibnu Hibban).

Dalam hadis lain menyebutkan hadis Nabi riwayat Muslim,Tirmidzi, Nasa'i, Abu Daud, Ibnu Majah, dan Ahmad, dari Umar Bin Khattab, Nabi SAW bersabda:

$$
\text { الذَّهَبُ بِالَوَرَقِ رِبًا إلاَّ هَاءَهَوَ هَاءَ (رواه مسلم) }
$$

Artinya :

"Jual beli emas dengan perak adalah riba kecuali (dilakukan) secara tunai." (H.R Muslim)

c. Kaidah Ushul fikih :

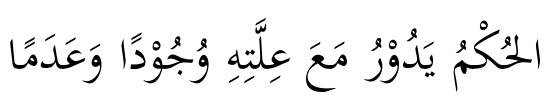

"Hukum berputar (berlaku) bersama ada atau tidak adanya 'illat."

d. Kaidah Fikih

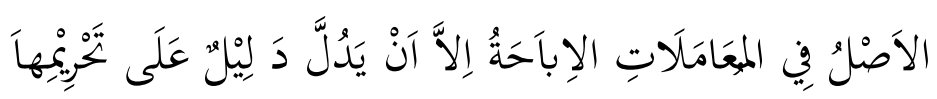

"Pada dasarnya, segala bentuk mu'amalat boleh dilakukan kecuali ada dalil yang mengharamkannya."

Jual beli emas secara tidak tunai juga bisa dilihat dari segi jual beli salam yang pembayarannya tidak diawal (diakhir), yang mana jual beli salam diperbolehkan oleh Nabi Muhammad SAW, yaitu dengan dalil-dalil antara lain QS. Al-Baqarah Ayat 282:

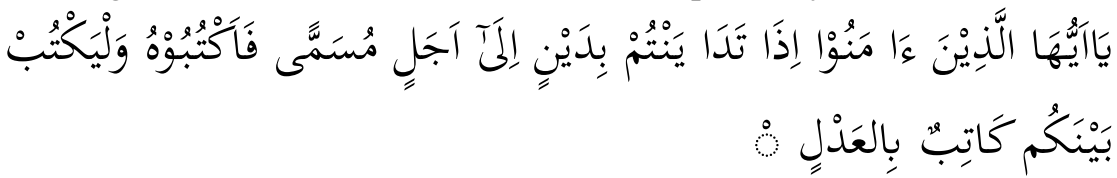

90 Analisis Transaksi Logam Mulia Secara Daring Dan Tidak Tunai Menurut Perspektif Fikih Muamalah

Indra Marzuki \& A. Nabila Mutiara 
Yang artinya :

"Hai orang-orang yang beriman, apabila kamu bermu'amalah tidak secara tunai untuk waktu yang ditentukan, hendaklah kamu menuliskannya. Dan hendaklah seorang penulis diantara kamu menuliskannya dengan benar."(QS.Al-Baqarah [2] : 282)

Perkembangan teknologi informasi dipastikan akan terus meningkat dengan berkembangnya dari zaman kezaman sehingga terbentuklah penjualan melalui media online. Beberapa dekade terakhir perkembangan tekologi informasi telah masuk kedunia perdagangan yang kemudian dikenal dengan nama e-commerce, pasar maya atau virtual market.

\section{Rukun dan Syarat Jual Beli Emas Tidak Tunai}

Rukun Jual Beli Emas Tidak Tunai sebagai berikut :

a. Pihak yang bertransaksi

Dalam jual beli emas tidak tunai, dua pihak yang bertransaksi harus ada dalam satu majelis misalnya dalam sebuah aplikasi yang sudah disediakan untuk mengisi data tersebut.

b. Barang atau objek jual beli emas Jual beli adalah aktivasi tukar menukar barang/jasa

c. Harga yang disepakati

Jika sudah ada penjual, pembeli dan barang yang mereka transaksikan, maka harus ada kesepakatan harga. Harga ini harus diketahui oleh kedua belah pihak (Ramli, 2005:17-18)

d. Akad atau seerah terima

Akad ini menunjukkan bahwa penjual dan pembeli sudah sepakat. Penjual sudah mau menyerahkan barang/objeknya, pembeli mau membayar sesuai dengan harga yang diisepakati.

Syarat Jual Beli Emas Tidak Tunai sebagai berikut :

a. Penjual dan pembeli melakukan transaksi secara sadar dan ridha. Artinya tidak ada unsur paksaan atau ancaman kepada salah satu pihak untuk melakukan transaksi.

b. Pihak yang bersangkkutan, pembeli dan penjual harus sudah dewasa, cakap, dan dalam kondisi sadar saat melakukan transaksi. Artinya tidak ada unsur penipuan, pengelabuan terhadap salah 
satu pihak karena sedang sedang tidak sadar atau masih anak dibawah umur.

c. Adanya akad alias kesepakatan jual beli kedua belah pihak. Artinya jual beli diikrarkan sehingga kedua bela pihak sama-sama sadar bahwa mereka melakukan jual beli dan saling mengetahui

d. Barang yang diperjual belikan adalah barang dimiliki sepenuhnya milik penjual, artinya barang tersebut bukan barang curian, pinjaman atau barang yang hanya dikuasai penjual.

e. Emas yang diperjual belikan adalah bukan barang terlarang atau haram. Maksudanya ialah emass tersebut masih bisa digunakan dan dapat dimanfaatkan.

f. Harga jual beli emas itu harus jelas ini adalah asas transparansi. Selain tanpa paksaan, jual beli emas harus mengedepankan kejujuran (Ramli, 2005:17-18).

\section{HASIL DAN PEMBAHASAN}

Analisis Transaksi Jual Beli Logam Mulia Secara Daring dan Tidak Tunai Serta Praktiknya Menurut Perspektif Fikih Muamalah

Kebutuhan merupakan sesuatu yang harus terpenuhi (baik barang maupun jasa) untuk kelangsungan hidup dan memenuhi kepuasan manusia sehingga dapat mempertahankan hidupnya. Untuk memenuhi kebutuhan hidup ada beberapa bentuk transaksi diantaranya adalah dengan jual beli. Jual beli merupakan pertukaran uang dengan barang yang dapat memenuhi kebutuhan hidup.

Transaksi jual beli dapat dilakukan secara tunai dan kredit (angsuran). Jual beli tunai merupakan jual beli yang dilakukan oleh kedua belah pihak (pembeli dan penjual) yang pembayarannya dilakukan cash. Hukumnya jual beli secara tunai menurut Islam ialah mubah, selama rukun, objek dan syarat jual beli terpenuhi dan sesuai dengan syariat Islam.

Sedangkan jual beli kredit (angsuran) merupakan jual beli yang dilakukan oleh kedua belah pihak yang pembayarannya dilakukan secara tunda. Jual beli secara tunda dalam fiqh disebutkan al-Bai alMuajjal. Ba"i al-Muajjal adalah jual beli dengan pembayaran ditangguhkan atau ditunda. Bai al- muajjal Arti kata al- muajjal adalah bentuk isim maf'ul dari kata ajjalah al-syakhsu syaian, artinya seseorang menunda sesuatu. Makna ajal berarti selesainya zaman atau

92 Analisis Transaksi Logam Mulia Secara Daring Dan Tidak Tunai Menurut Perspektif Fikih Muamalah

Indra Marzuki \& A. Nabila Mutiara 
masa. Ajal dalam istilah al-bai al-muajjal adalah waktu yang disepakati kedua belah pihak untuk menyerahkan harga barang yang dipenjual belikan. Menurut istilah fuqaha al-bai al-muajjal adalah jual beli yang mana pembayarannya ditunda, artinya penyerahan harganya ditunda sesuai waktu yang disepakati (Abdussatar, 2003:15).

Pembayaran tunda adalah hutang yang menjadi kewajiban pembeli. Istilah jual beli ialah bayar tunda berbeda dengan jual beli salam. Jual Beli Bayar Tunda, barang yang diperjualbelikan diserahkan pada saat akad sedangkan harganya ditunda penyerahannya, baik sebagian atau seluruhnya. Jual beli Salam ialah harga diserahkan pada saat akad, sedangkan barangnya ditunda penyerahannya. Menurut Zaid bin Ali adalah penjualan suatu barang secara tunda dengan harga yang lebih tinggi dari harga tunai merupakan salah satu bentuk transaksi yang sah dan dapat dibenarkan selama transaksi tersebut dilandasi oleh prinsip saling ridha antara kedua belah pihak (Karim, 2008:15).

Harga jual secara tunai dengan kredit sangat berbeda, kalau tunai harganya agak lebih murah, sedangkan kredit harga agak lebih mahal. Hal ini dikarenakan ada unsur kemanfaatan baik jual beli tunai maupun kredit. Jual beli secara tunda hukumnya adalah mubah. Nabi pernah melakukan pembelian gandum dengan pembayaran tunda, Nabi menggadaikan baju besi sebagai jaminannya. Perbuatan Nabi tersebut menjadi pijakan para ulama untuk menetapkan hukum mubah pada akad jual beli bayar di tunda.

Jual beli secara tunda merupakan hutang bagi pembeli. Maka dari itu satu sama lain sama-sama melakukan pencatatan. Pembayaran secara tunda (hutang/piutang) hendaklah mencatatnya (menuliskannya). Menurut Buya Hamka didalam tafsir Al-Azhar Juz 3 tentang surat Al-Baqarah ayat 282 yang mengemukakan beberapa hal yang relevan dengan akuntansi sebagai berikut: "Perhatikan tujuan ayat yang menyatakan kepada sekalian orang yang beriman kepada Allah supaya utang piutang itu ditulis, itulah dia yang berbuat sesuatu pekerjaan karena Allah, karena perintah Allah dilaksanakan. Sebab itu tidaklah layak berbaik hati kepada kedua belah pihak lalu berkata tidak perlu dituliskan karena kita selalu 
percaya dan mempercayai. Padahal umur kedua belah pihak sama-sama ditangan Allah."

Sedangkan dalam praktik jual beli emas secara virtual didasarkan pada objek fisik yang tidak terlihat. Namun menjadi sayarat sah nya proses transaksi tersebut dengan ketentuan hukum yang memenuhi syarat dan rukun sesuai dengan syariat Islam. Dalam proses transaksinya dalam sistem online melalui jaringan internet. Hubungan hukum yang terjadi antara para pihak yang menggunakan fasilitas internet tersebut berdasarkan objek hukum yang terlibat (Zainati, t.t:111).

Berdasarkan analisa penulis, Hukum Jual beli secara virtual menurut perspektif fikih ini membolehkan dan sah hukumnya dengan ketentuan hukum syara' yang telah ditetapkan. Hal yang menjadi syarat sah nya Ijab Qabul tersebut. Dalam hal ini terdapat syarat tambahan dalam transaksi Jual Beli secara Daring diantaranya yaitu :

1. Menjual barang yang halal.

2. Terpenuhi rukun-rukun dan syarat-syarat jual beli.

3. Adanya unsur saling keridhaan yang menjadi kesepakatan antara penjual dan pembeli dalam transaksi tersebut.

4. Adanya pengawasan hukum yang terpercaya yang mengakibatkan jual beli tersebut sesuai dengan aturan hukum, untuk menjamin keamanan jual beli secara daring agar tidak terjadi hal yang tidak diinginkan (Misbahuddin, 2012:32). Sebagaimana diputuskan oleh Majma' Al Fiqh Al-Islami (Devinisi Fiqih OKI) keputusan no.52 (3/6) tahun 1990, yang berbunyi:

"Apabila akad terjadi tetapi tidak dalam satu majelis saling bertemu tetapi hanya menggunakan media yang mana pembeli menggunakan pengisian data untuk melengkapi dari akad yang disepakati antara kedua belah pihak. Maka akad berlangsung dengan sampainya ijab dan qabul kepada masing-masing pihak transaksi. Walaupun dalam berjahuan maka ijab dan qabul yang terjadi adalah langsung seolaholah berada dalam satu tempat". (Salim, 2017:387).

Dalam transaksi menggunakan Internet, penyediaan aplikasi yang menyediakan barang merupakan pihak penjual website merupakan Ijab dan serta pengisian data yang dilakukan oleh pembeli merupakan Qabul. Dimana barang tersebut hanya di jelaskan pada

94 Analisis Transaksi Logam Mulia Secara Daring Dan Tidak Tunai Menurut Perspektif Fikih Muamalah

Indra Marzuki \& A. Nabila Mutiara 
media gambar serta dijelaskan spesifikasinya dengan lengkap. Dengan penjelasan yang dapat mempengaruhi harga jual barang. Setelah terjadinya akkad dan pembeli menyetujuinya maka pembeli melakukan pembayaran yang telah ditentukan. Setelah dikonfirmasi, si penjual baru mengirim barangnya melalui kurir jasa pengiriman barang. jadi, transaksi seperti jual beli secara virtual ini mayoritas para ulama menghalalkannya selama tidak ada unsur gharar atau ketidakjelasan, dengan memberikan spesifikasi barang tersebut dalam harga barang. Terdapat beberapa langkah yang dapat dilakukan agar jual beli secara daring menjadi benar dan sah menurut syariat Islam, diantaranya adalah:

1. Barang yang sudah jelas kehalalannya.

2. Memiliki manfaat serta nilai kegunaannya dalam menjual produk.

3. Barang yang telah di sepakati dapat diserahkan. Setelah proses yang telah disepakati maka barang dapat diproses sesuai dengan waltu yang ditentukan.

4. Memiliki perizinan hak atas menjual. Perizinan ini layaknya sebagai kuasa bagi penjual dalam proses transaksinya agar penjualannya dapat dipercaya.

5. Kesesuaian harga dengan kualitas barang, dalam jual beli secara daring banyak juga pembel pakaian yang telah dibeli secara online ternyata kualitas kainnya ukurannya tidak sesuai. Maka dari itu sebelum melakukan transaksi harus diperhatikan terlebih dahulu dan melihat hasil pembelian terdahulu apakah benar-benar sesuai dengan yang digambar atau tidak.

6. Bersikap jujur, dalam segala hal terutama dalam bisnis sangat dibutuhkan kejujuran bisnis tersebut. Bisnis secara daring ini memiliki kemudahan serta kelebihan, dalam bertransaksi namun bukan berarti tanpa masalah. Berbagai masalah dapat saja ditemui dari berbagai hal termasuk pada jual beli secara daring ini. Seperti kaitannya dengan amanah, bisa jadi ada orang yang melakukan pembelian atau pemesanan, namun setelah melakukan pembayaran, atau setelah mengirim uang muka, ternyata penjual berbohong ataupun penipuan dan tidak 
mengirimkan barang tersebut. Ataupun barang yang dikirim tidak sesuai dengan apa yang digambarkan di website nya atau tidak sesuai dengan apa yang penjual spesifikasikan sebelumnya (Napitupulu, 2013:134-138).

Berdasarkan hal diatas, maka Islam membolehkan umatnya melakukan jual beli secara daring, apabila sudah sesuai dengan hukum syara mengenai rukun dan syarat jual beli terpenuhi secara utuh. Setelah mengetahui rukun dan syarat sebagai salah satu bentuk sah nya transaksi tersebut maka peraturan media transaksi elektronik di Indonesia mensyaratkan bahwa dalam bertransaksi harus mempunyai etika baik. Dalam mazhab Asy-Syafi'i menyatakan bahwa dalam transaksi tidak ada unsur hati didalamnya tetapi dalam fikih modern Mabda' Husn An-Niyyah yaitu unsur etika baik dalam fikih Islam berhubungan langsung dengan akhlak atau tingkah laku tersebut merupakan kaidah-kaidah syariat islam yang terpisahkan. Jadi prinsip memiliki etika baik bukan hanya dalam batin saja, tetapi merupakan tingkah laku dalam perbuatan yang sesuai dengan hukum-hukum syariat Islam dimana pada etika baik terdapat pada semua hukum, baik hukum ibadah atau muamalah (Napitupulu, 2013: 134-138).

Sehingga dalam hukum KHU Perdata disebutkan bahwa pasal 1457 yaitu : "jual beli adalah suatu keridhaan antara pihak satu dengan pihak yang mengikat dirinya untuk menyerahkan suatu kebendaan, dan pihak yang lain untuk membayar harga yang telah dijanjikan." Selain dari unsur keridhaan dalam bertransaksi disebutkan juga bahwa tidak ada unsur paksaan dan jika dalam perikatan ada unsur paksaan yang mengandung penipuan atau kekhilafan didalamnya maka dapat melaporkan suatu tuntutan atau membatalkannya. Karena tidak banyak diantara yang melakukan transaksi tersebut ada yang melakukan kecurangan, ketidak jujuran dan hanya untuk mengambil keuntungan sepihak tanpa memikirkan pihak lain yang dirugikan jadi dalam transaksi ini sangat dibutuhkan kejujuran dan etika baik didalamnya agar tidak terjadi hal-hal yang tidak di ingingkan kedua belah pihak dalam bertransaksi.

Perlu diperhatikan bahwa dalam bertransaksi dapat milih dan milah media atau toko secara daring yang di inginkan sesuai kebutuhan dimana dapat menanyakan langsung kepada pemilik toko untuk mengecek barang yang di inginkan jika dalam bertransaksi melalui

96 Analisis Transaksi Logam Mulia Secara Daring Dan Tidak Tunai Menurut Perspektif Fikih Muamalah

Indra Marzuki \& A. Nabila Mutiara 
media aplikasi room chat misalnya dan penjual memberikan pelayanan yang ramah dan fast respont maka bisa dilakukan perjanjian tersebut jika pembeli telah sepakat dengan barang yang di inginkan sesuai menurut rukun dan syarat maka terjadilah proses transaksi tersebut secara media data yang telah disediakan.

\section{Analisis Kesesuaian Transaksi Jual Beli Logam Mulia Secara Daring dan Tidak Tunai Menurut Perspektif Fikih Muamalah}

Transaksi jual beli logam mulia secara daring ini sudah banyak dilakukan oleh influaser, pengusaha dan media online lainnya. Karena selain tidak memakan waktu dan tempat untuk alokasi penjualan juga memudahkan dalam melakukan pembayaran karena sudah banyak cara yang modern bisa melakukan transaksi pembayaran secara daring, mulai dari pembayaran melalui media transfer dari antar bank maupun ke bank lainnya, media OVO, Dana, Go Pay, Link Aja, Shopee Pay dan lain sebagainya. Untuk melakukan transaksi ini harus diperhatikan betul dari segi orang yang menjual barang tersebut, dari segi pembayaran ataupun dari segi pengiriman yang dilakukan, apakah sudah aman ataupun tidak.

Dari contoh aplikasi yang saya sudah bahas pada bab sebelumnya mengenai aplikasi Lakuemas dan aplikasi Tamasia yang menjual beli emas secara tidak tunai, disini kedua aplikasi ini mempunyai perbedaan antara satu sama lain dari segi penjualannya, dari segi mengambil emas hingga dari segi pembayarannya. Di aplikasi Lakuemas ini melakukan transaksi melalui media aplikasi tersendiri dengan cara memesan logam mulia sesuai yang di inginkan ukuran gram yang dibutuhkan dan sesuai dengan budget kita, kemudian membayarnya dengan pilihan media yang sudah ditentukan pada aplikasi seperti melalui transfer bank, setelah melakukan pembayaran media aplikasi menkonfirmasikan dan menproses hasil pesanan pelanggan tersebut, kemudian jika pelanggan tersebut ingin menarik logam mulia emas tersebut bisa langsung datang ke ATM fisik emas yang sudah disediakan yang kini aplikasi Lakuemas ini satu-satunya yang memiliki ATM tarik fisik di Indonesia sehingga pelanggan dengan mudah mengambil emas yang sudah dipesannya. Sedangkan pada 
aplikasi Tamasia sendiri jika ingin melakukan pembelian logam mulia yaitu dengan cara memesannya melalui aplikasi Tamasia, Bukalapak ataupun melalui media Shopee, kemudian memilih ukuran gram emas yang di inginkan, setalah selesai kemudian membayarkannya. Aplikasi Tamasia memiliki dua pilihan pembayaran yaitu dengan cara tunai ataupun dengan cara mengangsur. Jika memilih pembayaran secara mengangsur maka ada jangka waktu yang sudah ditentukan dalam melakukan pembayaran ini, setelah selesai mengangsur, maka pihak Tamasia akan memproses pemesanan pelanggan, kemudian pelanggan mendapatkan informasi bahwa pemesanan berhasil, jika sudah selesai pelanggan ingin mengambil emasnya maka bisa langsung diantarkan ke tempat tujuan pelanggan dengan jasa kurir yang sudah disediakan.

Jual beli emas tidak tunai atau kredit adalah cara menjual atau membeli barang dengan pembayaran yang ditangguhkan atau diangsur. Emas yang sering menjadi salah satu media investasi tak luput dari pengaruh sistem jual beli angsuran. Dalam presfektif fikih muamalah yang telah dikemukakan bahwa jual beli emas secara tidak tunai ini dibolehkan selama emas tersebut tidak menjadi nilai tukar (alat pembayaran,uang) dimana pendapat ulama yang membolehkan seperti Ibnu Qayyim dan Ibnu Taimiyyah dan ulama kontemporer lainnya bahwa pendapat ulama ini membolehhkannya transaksi ini untuk memudahkan kemaslahatan ummat dalam bertransaksi agar tidak terjadi utang-piutang ataupun riba yang menyesatkannya nanti, sehingga dikeluarkanlah fatwa DSN-MUI N0.77/DSN-MUI/V/2010 tentang jual beli emas secara tidak tunai yang memiliki sependapat dengan ulama tersebut walaupun dalam dikeluarkannya fatwa ini menimbulkan perdebatan sehingga dapat memecahkan masalah ini.

Dari perbedaan pendapat tersebutt dapat disimpulkan bahwa kesesuaian presfektif fikih muamalah seperti ulama Ibnu Qayyim dan Ibnu Taimiyyah dalam membolehkannya transaksi jual belli emas secara tidak tunai dengan Dewan Syariah Nasional Majelis Ulama Indonesia (DSN_MUI) pada fatwanya dengan jelas menyatakan bahwa jual beli emas boleh hukumnya dengan syarat selama emas tidak menjadi alat tukar yang resmi, baik jual beli biasa maupun jual beli dalam murabahah. Sehingga DSN memberikan batasan-batasan dalam membolehkannya jual beli emas tersebut yang merupakan implikasi dari jual beli emas secara tidak tunai sebagai berikut:

98 Analisis Transaksi Logam Mulia Secara Daring Dan Tidak Tunai Menurut Perspektif Fikih Muamalah

Indra Marzuki \& A. Nabila Mutiara 
1. Dalam bertransaksi tidak boleh adanya tambahan harga selama perjanjian walaupun adanya penundaan pembayaran setelah jatuh tempo, karena jika ada penambahan didalamnya maka jatuhnya seperti bunga (riba). Karena dalam penjualan emas tersebut selalu ada influktuasi harganya dalam jangka waktu tertentu. Seperti yang telah dijelaskan fatwa DSN-MUI dalam pasal bahwa tidak ada penambahan harga didalamnya, walaupun ada penundaan waktu yaitu pembayaran ditangguhkan (angsuran).

2. Tidak boleh adanya pemindahan kepemilikan selama emas masih dalam masa angsuran

3. Emas yang masih dalam angsuran (kredit) boleh sebagai barang jaminan atau Rahn.

Jika ditinjau dari presfektif fikih muamalah dan fatwa DSN dalam melakukan transaksi pada media aplikasi lakuemas dan tamasia dengan memikirkan untuk jangka waktu panjang maka dapat dilakukan sesuai dengan persyaratan dan unsur-unsur yang telah ditetapakan menurut rukun dan syarat jual beli maka boleh dilakukan selama didalamnya tidak ada unsur gharar atau penambahan harga selama perjanjian. Tetapi perlu hati-hati dalam memilih media aplikasi berbasis online seperti kedua aplikasi ini karena tidak semua aplikasi onnline yang berbasis penjualan emas memiliki sertifikat usaha ataupun sudah terdaftar dii OJK jadi harus dipastikan terlebih dahulu sebelum melakukan transaksi tersebut.

\section{PENUTUP}

\section{Kesimpulan}

1. Transaksi jual beli logam mulia secara daring dan tidak tunai melalui aplikasi lakuemas dan tamasia ini dilakukan menggunakan platfroam digital yang telah disediakan dimana pelanggan yang ingin bertransaksi dapat membuka aplikasi lakuemas dan tamasia tersebut sehingga dapat memudahkan serta aman dalam pelaksanaanya serta menurut perspektif fikih muamalah seperti Ibnu Qayyim dan Ibnu Taimiyyah membolehkan jual beli emas secara tidak tunai ini untuk 
membantu perekonomian dan memudahkan ummat dalam kemaslahatan bertransaksi. Sebagaimana yang dikemukakan para ulama yang membolehkan sebagai berikut:

a. Bahwa emas dan perak adalah barang (sil'ah) yang dijual dan dibeli seperti halnya barang biasa, dan bukan lagi tsaman (harga, alat pembayaran, uang)

b. Manusia sangat membutuhkan untuk melakukan jual beli emas. Apabila tidak diperbolehkannya jual beli emas secara angsuran atau tidak tunai, maka rusaklah kemaslahatan manusia dan mereka akan mengalami kesulitan.

c. Emas dan perak setelah dibentuk menjadi perhiasan berubahlah menjadi seperti pakaian dan barang, bukan lagi merupakan tsaman (harga, alat pembayaran, uang). Oleh karena itu tidak terjadi riba karena riba (dalam pertukaran atau jual beli antara perhiasan dengan harga (uang), sebagaimana terjadi riba (dalam pertukaran atau jual beli) antara (uang) dengan barang lainnya, meskipun bukan dari jenis yang sama.

d. Sekiranya pintu (jual beli emas secara angsuran) ini ditutup, maka tertutuplah pintu utang piutang, masyarakat akan mengalami kesulitan yang tidak terkira.

2. Transaksi jual beli logam mulia secara daring dan tidak tunai melalui aplikasi lakuemas dan tamasia ini telah sesuai dengan prinsip syariah dan perspektif fikih muamalah yang telah terpenuhi syarat dan rukun jual beli serta tidak terdapat unsur gharar didalamnya. Aplikasi lakuemas saat ini telah memiliki llisensi surat izin usaha perdagangan (SIUP) dan tanda daftar perusahaan (TDP) untuk perdagangan emas logam mulia, selain itu lakuemas sedang dalam proses pendaftaran BAPPEBTI, sedangkan aplikasi tamasia telah berada dibawah pengawasan BAPPEBTI (Badan Pengawasan Perdagangan Bejangka Komoditi) dimanaa peuahaan emas digital harus berada dibawah regulasi BAPPEPTI dan tamasia juga sudah memiliki legalitas selaku perusahaan yang sah menurut perundangan yang juga telah terdaftar pada kementrian komunikasi dan informatika Republik Indonesia.

100 Analisis Transaksi Logam Mulia Secara Daring Dan Tidak Tunai Menurut Perspektif Fikih Muamalah

Indra Marzuki \& A. Nabila Mutiara 


\section{Saran}

Berdasarkan kesimpulan yang telah dipaparkan, maka peneliti memberikan saran penelitian sebagai berikut :

1. Kepada media aplikasi lakuemas dan tamasia ini semoga kedepannya dapat berkembang dan memiliki cabang dimanamana sehingga dapat memudahkan seluruh pengguna media tersebut. Sehingga memiliki cabang perusahaan disetiap daerah yang dapat dikunjungi secara langsung ditempat-tempat terdekat jika terjadi masalah atau ingin menyaksikan lanngsung kantor perusahaan tersebut.

2. Kepada peneliti selanjutkan penulis menyarankan jika ingin melakukan transaksi jual beli secara daring dan tidak tunai seperti ini maka perlu diperhatikan kesesuaiannya terhadap prinsip syariah dan syariat Islam yang sesuai dengan rukun dan syarat yang telah ditentukan. Serta dalam peneliitian ini semoga bermanfaat bagi penelitian selanjutnya jika penelitian penulis ini masih banyak kekurangan dan ketidak sempurnaan dalam melakukan penulisan ini maka penulis menyarankan untuk dapat menambahkan atau melengkapi hasil informasi penelitian selanjutnya dalam mencari data-data dan informasi yang terkait dengan penelitian selanjutnya butuhkan.

\section{DAFTAR PUSTAKA}

Abdul, Muhammad Aziz Azzam. (2010). Figh Muamalah: Transaksi Dalam Islam, Penerjemah : Nadirsyah Hawari. Jakarta: Amzah.

Abdullah, Abu Muhammad bin Yazid Ibn Majah Al-Quzawaeni, (t.t). Sarah Ibn Majah, Juz II, Darul Fikri, Beirut

Abdussatar. (2003). al-Bai'al-muajjal, al-ma'had al-Islami lilbuhus wa tadrib, Jeddah.

Ahmad, Ali Al-Nadawi. (1999). Mawsu'ah al-Qawa'id al-Dhawabith alFiqhiyah al-Hakimah li-al-Mu'amalat al-Maliyah fi al-Figh al-Islamiy. Riyadh: Dar Alam al-Ma'rifah. 
Abi, Muhammad Abdiillah Bin Ismail Al-Bukhari. (2000). "Shahih Bukhari", Juz 2 Terjemahan Ahmad Sunarto. Surabaya : AlHidayah.

Al-Mustafa, Bigha, et al., (1989). Al-Figh Al-Manhaji, Damascus, Dar AlUlum Al-Insaniyyah, Juz 6.

Al-Yusuf, Qardawi, Abdul Karim al-tufi. (1996). Risalah al-imam al-tufi taqadiim al-maslahah fi al-Mu'amalat 'ala al-Nas, Kairo: Jami'atul Azhar.

Az-zuhaili, Wahbah. (t.t). Al-Wajiz fi Ushuli al-Figh. Beirut : Dar-fikr.

Az-Zuhaili, Wahbah. (2010). Fiqih Imam Syafi'i. Jakarta Al-Mahira.

Dewan Syariah Nasional MUI, Fatwa No.77/DSN-MUI/V/2010 Tentang Jual Beli Emas Secara Tidak Tunai.

Karim, Adiwarman. (2008). Sejarah Pemikiran Ekonomi Islam. Jakarta: Rajagrafindo Persada.

Kitab Undang-Undang Hukum Perdata. (2013). Jakarta:Indonesia Legal Center Publishing.

M.Daud, Ali H. (1991). Asas-asas Hukum Islam. Jakarta: Rajawali Pers.

Mardani. (2012). Fiqih Ekonomi Syari'ah. Jakarta : Kencana.

Misbahuddin. (2012). E-commerce dan Hukum Islam. Makassar Alauddin University Press, Makassar.

Napitupulu, R. M. (2015). Pandangan Islam Terhadap Jual-Beli Online," dalam Tijarah, Vol. 1(2).

Amin, A. R. (2012). Satanic Finance. Jakarta: Ufuk Publising House.

Rizqi, Muhammad Romdhon. (2015). Jual Beli Online Menurut Madzhab Asy-Syafi'i. Surabaya: Garuda Mas Sejahtera.

Rizqi, Romdhon Muhammad. (2015). Jual Beli Online Menurut Madzhab Asy-Syafi'i. Pustaka Cpasung.

Salim, Munir. (2017). Jual-Beli Secara Online Menurut Pandangan Hukum Islam, Jurnal al-Daulah, Vol. 6(2).

Shan'aini, As, Terjemahan Subulussalam Jilid III. (1995)., Terj. Abu Bakar Muhammad, Subulus Salam II. Surabaya: Al-Ikhlas.

102 Analisis Transaksi Logam Mulia Secara Daring Dan Tidak Tunai Menurut Perspektif Fikih Muamalah 
Undang-undang nomor 11 tahun 2008 tentang Informasi dan Transaksi Elektronik, Bab V, Pasal 17, ayat 2.

Undang-undang Republik Indonesia Nomor 8 Tahun 1999, Perlindungan Konsumen.

Wahab, Abdul Khallaf. (1972). Mashadir al-Tasyri' al-Islami fi ma la Naskh fih. Kuwait: Dar al-Qolam.

Wardi, Ahmad Muslich. (2013). Fiqh Muamalah. Jakarta :Amzah.

Zaenudin, Ali. (2016). Metode Penelitian Hukum. Jakarta:Sinar Grafika.

Zainal, Arifin. (2014). Penelitian Pendidikan. Bandung: Remaja Rosdakarya.

https://wwww.centralmegakencana.com Diakses pada hari Rabu, 30 Juni 2021, Pukul 21:59 WITA.

https://wwww.Lakuemas.com.//about/. Diakses pada hari Rabu, 21 Juli 2021, Pukul 02.44 WiTA.

https://wwww.Lakuemas.com.//about/. Diakses pada hari Sabtu, 17 Juli 2021, Pukul 18:00 WITA

https://www.tamasia.co.id/about/ Diakses pada hari Selasa, 27 Juli 2021, Pukul 14:30 WITA. 